\title{
Effects of guavira fruit (Campomanesia adamantium) peel extract on performance and meat quality of broilers
}

\author{
M.L. Lohmann1, C. Eyng ${ }^{1 \#}$, R.V. Nunes', E.J.S. Argandona ${ }^{2}$, C.A.C. Correia ${ }^{2}$, T.L. Köhler ${ }^{1}$ \& \\ A.P.G.C. Costa ${ }^{1}$ \\ ${ }^{1}$ Western Paraná State University, - Unioeste, Department of Animal Science, Marechal Cândido Rondon, Paraná, \\ Brazil. \\ ${ }^{2}$ Federal University of Grande Dourados (UFGD), Department of Animal Science, Dourados, Mato Grosso do Sul, Brazil.
}

(Submitted 6 July 2020, Accepted 10 October 2020, Published 6 January 2021)

\author{
Copyright resides with the authors in terms of the Creative Commons Attribution 4.0 South African Licence. \\ See: http://creativecommons.org/licenses/by/4.0/za \\ Condition of use: The user may copy, distribute, transmit and adapt the work, but must recognise the authors and the South African \\ Journal of Animal Science.
}

\begin{abstract}
This article assessed the performance, carcass yield, and meat quality of finishing broilers fed increasing levels of hydroethanolic extract of guavira fruit peel (HEGP) were assessed. A total of 480 , threeweeks-old male broilers were randomly allocated to dietary levels of $\operatorname{HEGP}(0,100,200,300,400$, and 500 $\mathrm{mg} / \mathrm{kg}$ ), with five replicates and 16 birds each. There was a quadratic effect of HEGP inclusion on weight gain (WG) and feed conversion ratio (FCR), with the greatest WG and FCR being calculated at levels of 314 and $219 \mathrm{mg} / \mathrm{kg} \mathrm{HEGP}$, respectively. Broilers fed diets containing the extract had better performance than those fed an extract-free diet. There was no effect of extract inclusion on carcass yield and cuts. There was a quadratic effect of HEGP inclusion on $a^{*}$ (redness) of thigh meat at 15 min post-mortem, and on waterholding capacity (WHC), with the lowest and highest values being calculated at $270 \mathrm{mg} / \mathrm{kg}$ and $263 \mathrm{mg} / \mathrm{kg}$ HEGP, respectively. There was a quadratic influence of HEGP inclusion on the malonaldehyde content at 30-day storage, with highest value being calculated at $218 \mathrm{mg} / \mathrm{kg} \mathrm{HEGP.} \mathrm{Dietary} \mathrm{inclusion} \mathrm{of} 219 \mathrm{mg} / \mathrm{kg}$ of HEGP resulted in better FCR for broilers in the finishing phase but without improvement in meat quality.
\end{abstract}

Keywords: Cerrado fruit, feed additives, flavonoids, meat quality.

"Corresponding author: cinthiaeyng@hotmail.com

\section{Introduction}

For decades it has been common practice in the poultry industry to manipulate the intestinal health of broiler chickens with antibiotics in subtherapeutic concentrations. The dietary inclusion of these substances contributed to efficient nutrient absorption and assimilation, thereby favouring productive performance and reducing feed costs (Oleforuh-Okoleh et al., 2015). Despite these benefits, the use of antibiotics to enhance broiler performance was correlated with the development of bacterial resistance in humans, which is a public health concern (Garcia-Migura et al., 2014).

Mechanisms of action have been observed in natural extracts containing polyphenols and flavonoids that are similar to those of performance-enhancing antibiotics (Surai et al., 2014). Plant extracts are natural non-toxic products that could be used as natural feed additives without inducing the resistance of microorganisms (Huyghebaert et al., 2011). Guavira (Campomanesia adamantium) fruit extracts are among these potential natural additives. This fruit from the Cerrado biome has aroused interest among researchers because of its significant levels of proteins, vitamins, minerals, and fatty acids (Vallilo et al., 2006).

In addition to its nutritional value, guavira contains bioactive substances such as ascorbic acid and phenolic compounds. Flavonoids, a class of polyphenolic compounds, are the major constituents, and include isoquercetin and quercetin (Pascoal et al., 2011). These substances may have antioxidant, antimicrobial, or immunostimulant activity (Pereira et al., 2012; Viecili et al., 2014; Capeletto et al., 2016). Phenolic compounds may inhibit the adhesion of pathogenic bacteria to the intestinal epithelia (Jamroz et al., 2006; Windisch et al., 2008), influence digestive processes (Ader et al., 2000), and modulate the animal's immune system (Kamboh et al., 2015), with consequent improvements in performance. Moreover, these compounds can improve meat quality by acting as antioxidant agents, reducing the lipid oxidation process by 
neutralizing reactive oxygen molecules and preventing toxin formation during meat processing and cooking (Jiang \& Xiong, 2016).

Although guavira contains these compounds, the effects of using it in broiler nutrition have not yet been reported. Therefore, this study aimed to evaluate the effects of feeding increasing levels of HEGP on the performance, carcass yield, and meat quality of finishing broilers. The authors hypothesized, therefore, that the bioactive substances of guavira fruit peel extract will improve the performance and meat quality of broilers.

\section{Material and Methods}

The experiment was carried out at the Poultry Study Centre of Western Paraná State University, Unioeste, Marechal Cândido Rondon Campus, PR, Brazil. The birds were cared for according to ethical principles for animal experimentation established by the Brazilian Society of Laboratory Animal Science (SBCAL) and National Council for the Control of Animal Experimentation (CONCEA). The protocol of this experiment was approved by the Committee on Ethics in the Use of Animals of Western Paraná State University (Protocol \#38/17). All efforts were made to minimize animal suffering.

A total of 600 one-day-old Cobb $500^{\circledR}$ male broiler chickens were housed in an experimental shed, divided into $1.95 \mathrm{~m}^{2}$ pens (experimental unit), with a concrete floor and pine wood shavings reused five consecutive times. Each unit had access to a tubular feeder and a nipple-type drinker. The lighting programme followed the lineage manual recommendations. The temperature and relative humidity were measured daily by digital thermo-hygrometers (Instrutemp, ITHT 2250, São Paulo, Brazil) at bird height inside the facility. The temperature inside the shed was controlled with exhaust fans and evaporative cooling pads, set at maximum and minimum temperatures of $24.80{ }^{\circ} \mathrm{C}$ and $21.51{ }^{\circ} \mathrm{C}$ and maximum and minimum humidity of $74.99 \%$ and $63.82 \%$.

For the first 21 days of rearing, all birds were kept under the same nutritional, management, and environmental conditions. The diets were formulated according to Rostagno et al. (2017) for intermediateperformance male broilers. On day 21, birds were weighed individually, divided into weight classes, and 480 birds, with an average weight of $1.007 \pm 6.5 \mathrm{~g}$, were redistributed in a manner that equalized pen weights and variances into a completely randomized design with six dietary treatments, with five replicates and 16 birds per unit. The treatments consisted of increasing levels of HEGP $(0,100,200,300,400$, and 500 $\mathrm{mg} / \mathrm{kg}$ ).

Guavira fruit was purchased in Ponta Porã - MS, Brazil and processed at the Faculty of Biological Sciences of the Federal University of Grande Dourados in Dourados - MS, Brazil. The fruits were washed and immersed in a sanitized solution of $0.66 \%$ sodium dichloroisocyanurate dehydrate (Diversey Chemical Industry, São Paulo, Brazil) for 15 min. Afterwards, the fruit was pulped, and the peel was dried in an oven at $40{ }^{\circ} \mathrm{C}$ with an airflow of $0.5 \mathrm{~m}^{3} / \mathrm{s}$ for 36 hours. The dried material was packaged in low-density polyethylene package and stored at room temperature $\left(25^{\circ} \mathrm{C}\right)$ until the extract was produced. The extract was obtained by Soxhlet extraction using $150 \mathrm{~g}$ of the sample and $750 \mathrm{~mL}$ of $70 \%$ absolute ethyl alcohol (1:5 w/v ratio) (Synth, São Paulo, Brazil). The extraction was carried out at $80^{\circ} \mathrm{C}$ for three hours, and then the solvent was removed under vacuum using a rotary evaporator (Fisatom model 810) to yield the aqueous extract, which was stored in amber glass vials at $7 \stackrel{\circ}{\mathrm{C}}$ until analysis.

The bioactive compounds were extracted according to Singleton and Rossi (1965), with modifications to determine the total polyphenol and flavonoid content of the extract. Two millilitres of the extract were homogenized with $2 \mathrm{~mL}$ of methanol (Sigma Aldrich, São Paulo, Brazil) in Falcon tubes. Subsequently, the tubes were placed in a homogenizer (Criemaq C38, São Paulo, BR) for 10 min and then centrifuged (Centrifuge Kasvi K14-4000, Kasvi, São Paulo, BR) at $3000 \mathrm{rpm}$ for $20 \mathrm{~min}$. The supernatant was used directly for the measurements.

The total concentration of phenolic compounds in HEGP was determined according to Singleton and Rossi (1965), with modifications. An aliquot of the supernatant $(125 \mu \mathrm{L})$ was homogenized with $125 \mu \mathrm{L}$ of Folin-Ciocalteu reagent (Sigma Aldrich, São Paulo, Brazil) (1:1 v/v deionized water) and sodium carbonate (Sigma Aldrich, São Paulo, Brazil) $(28 \mathrm{~g} / \mathrm{L})$ in a total volume of $2.25 \mathrm{~mL}$. After incubation in the dark at room temperature $\left(25^{\circ} \mathrm{C}\right.$ ) for $30 \mathrm{~min}$, absorbance was measured in a spectrophotometer (Evolution ${ }^{\mathrm{TM}} 300 \mathrm{e}$ Thermo Scientific) at $750 \mathrm{~nm}$. The results were expressed as milligrams of gallic acid equivalents (GAE) per litre of HEGP (mg GAE/L), using a standard curve constructed with gallic acid (Dinâmica Química Contemporânea LTDA, São Paulo, Brazil) at 0 - $300 \mathrm{mg} / \mathrm{L}$. All analyses were performed in triplicate.

The flavonoid content was established with the aluminium chloride $\left(\mathrm{AlCl}_{3}\right)$ method (Buriol et al., 2009) with modifications. Briefly, $300 \mu \mathrm{L}$ of the supernatant was mixed with $150 \mu \mathrm{L} \mathrm{AlCl}_{3}(5 \% \mathrm{w} / \mathrm{v}$ in methanol) (Sigma Aldrich, São Paulo, Brazil), and the volume was made up to $3000 \mu \mathrm{L}$ with methanol (Sigma Aldrich, São Paulo, Brazil). After incubation in the dark at room temperature $\left(25^{\circ} \mathrm{C}\right)$ for $30 \mathrm{~min}$, absorbance was measured in a spectrophotometer (Evolution ${ }^{\mathrm{TM}} 300$ e Thermo Scientific) at $425 \mathrm{~nm}$. A quercetin (Sigma 
Aldrich, São Paulo, Brazil) standard curve was prepared, and the results were expressed as milligrams of quercetin equivalents (QE) per litre of HEGP (mg QE/L).

The experimental isoproteic and isocaloric diets were based on corn and soybean meal according to Rostagno et al. (2017) for intermediate-performance male broilers (Table 1). The HEGP was added to the diets by replacing kaolin and by mixing it into the soybean oil. The basal diet was formulated with Super $\mathrm{Crac}^{\circledR}$ 6.2 Premium software. The birds had ad libitum access to water and feed in the mash form in both periods ( 1 - 21 and 22 - 42 days).

Table 1 Feed ingredients and nutrient contents of basal diet

\begin{tabular}{|c|c|c|c|}
\hline Ingredients & $\mathrm{g} / \mathrm{kg}$ & Nutrients & \\
\hline Corn & 639.00 & Metabolizable energy, MJ/kg & 13.25 \\
\hline Soybean meal, $45 \%$ crude protein & 279.98 & Crude protein, $\mathrm{g} / \mathrm{kg}$ & 180.00 \\
\hline Soybean oil & 41.59 & Calcium, $\mathrm{g} / \mathrm{kg}$ & 7.17 \\
\hline Monocalcium phosphate & 13.14 & Available phosphorus, $\mathrm{g} / \mathrm{kg}$ & 3.49 \\
\hline Limestone & 9.08 & Sodium, g/kg & 2.04 \\
\hline $\mathrm{NaCl}$ & 4.84 & Digestible lysine, $\mathrm{g} / \mathrm{kg}$ & 10.88 \\
\hline DL-methionine, $98 \%$ & 3.09 & Digestible methionine + cysteine, $\mathrm{g} / \mathrm{kg}$ & 8.05 \\
\hline L-lysine sulphate, $50.7 \%$ & 5.03 & Digestible threonine, $\mathrm{g} / \mathrm{kg}$ & 7.18 \\
\hline L-threonine, $98 \%$ & 1.15 & Digestible tryptophan, $\mathrm{g} / \mathrm{kg}$ & 1.98 \\
\hline Vitamin supplement $^{1}$ & 1.50 & & \\
\hline Mineral supplement ${ }^{2}$ & 0.50 & & \\
\hline Kaolin ${ }^{3}$ & 0.50 & & \\
\hline Choline chloride & 0.60 & & \\
\hline
\end{tabular}

(per kg of the diet) vitamin $A: 16.500 \mathrm{UI}$, vitamin $\mathrm{D}_{3}: 60.000 \mathrm{UI}$, vitamin $\mathrm{E}: 825 \mathrm{UI}$, vitamin $\mathrm{K}_{3}: 4.5 \mathrm{mg}$, vitamin $\mathrm{B}_{1}: 3.45$ mg, vitamin $B_{2}: 10.5 \mathrm{mg}$, vitamin $B_{6}: 6 \mathrm{mg}$, vitamin $B_{12}: 37.5 \mathrm{mcg}$, pantothenic acid: $18 \mathrm{mg}$, nicotinic acid: $90 \mathrm{mg}$, folic acid: $3 \mathrm{mg}$, biotin: $0.375 \mathrm{mg}$, selenium: $0.45 \mathrm{mg}$

iron: $150 \mathrm{mg}$, copper: $30 \mathrm{mg}$, manganese: $195 \mathrm{mg}$, zinc: $195 \mathrm{mg}$, iodine: $3 \mathrm{mg}$

${ }^{3}$ The hydroethanolic extract of guavira peel replaced kaolin.

At 21 and 42 days old, the birds were weighed, as well as the leftover feed at 42 days to calculate average feed intake (AFI), weight gain (WG), and feed conversion ratio (FCR). Mortality was recorded daily for later correction of data on AFI and FCR (Sakomura \& Rostagno, 2016). The mortality rate was considered normal for this facility, being less than $2 \%$ for all groups.

At 42 days old, two representative birds per experimental unit (mean weight $\pm 5 \%$ ) were selected to determine yields of carcass and special cuts. The birds were weighed individually, slaughtered by electronarcosis (CONCEA normative resolution no. 37 of 15 February 2018) and then bled, plucked, and eviscerated. The carcass yield was calculated as the proportion of eviscerated carcass weight (without head, feet, neck, and abdominal fat) to live weight. The yields of cuts (breast, legs, and wings) were calculated relative to the eviscerated carcass weight. Abdominal fat was regarded as all adipose tissue around the cloaca and attached to the gizzard. Concomitantly, the right breast muscle and thigh were used for $\mathrm{pH}$ and meat colour evaluation. Afterwards, the cooking loss (CL), water-holding capacity (WHC), and shear force (SF) were determined using the breast muscle. The left thigh was used to determine lipid oxidation (TBARS).

Meat colour and $\mathrm{pH}$ were determined at $15 \mathrm{~min}$ and again at 24 hours post tmortem. $\mathrm{pH}$ determination was performed directly on the breast muscle (Pectoralis major) and thigh muscle, using a $250 \mathrm{Testo} \AA \mathrm{pH}$ meter (Testo Argentina S.A., Buenos Aires, Argentina). Meat colour was determined with a CR-400 Konica Minolta colorimeter. CIELab values of $L^{*}$ (lightness - from $0=$ black to $100=$ white), $a^{*}$ (redness $=+a^{*}$; greenness $=-a^{*}$ ), and $b^{*}$ (yellowness $=+b^{*}$; blueness $=-b^{*}$ ) were evaluated in three regions of the upper, middle, and lower inner breast and inner thigh (Honikel, 1998).

Water-holding capacity was analysed according to Nakamura and Katok (1985). One-gram samples of raw breast muscle were wrapped in filter paper and centrifuged (Centrifuge Kasvi K14-4000, Kasvi, São Paulo, BR) at $1500 \mathrm{rpm}$ for $4 \mathrm{~min}$. The samples were then weighed and oven-dried at $70^{\circ} \mathrm{C}$ for 12 hours. 
Then the dried samples were weighed again to determine the WHC as a percentage (weight of the meat sample after centrifugation - weight of the sample after drying/initial weight of the raw sample $\times 100$ ).

Breast fillets were weighed, wrapped in aluminium foil, and kept on an electrically heated plate at 180 ${ }^{\circ} \mathrm{C}$ until the internal temperature of the breast reached $80 \stackrel{\circ}{\circ}$ to determine $\mathrm{CL}$. The fillets were weighed after cooling to room temperature to obtain the post-cooking weight (Honikel, 1998).

The SF analysis was performed with the same steaks. The samples were trimmed, cut into three pieces $(1.0 \times 1.0 \times 1.3 \mathrm{~cm})$, and sheared perpendicular to the muscle fibre orientation with a TA.XT2i texturometer (Stable Micro Systems, Jarinu, Brazil) coupled to a calibrated 29 Warner-Bratzler SF mechanical probe, with $5-\mathrm{kg}$ capacity and crosshead speed set at $20 \mathrm{~cm} / \mathrm{min}$ (Fronning \& Uijttenboogaart, 1988), providing the measurement of the SF in kilogramme force $\left(\mathrm{kgf} / \mathrm{cm}^{2}\right)$.

The determination of TBARS in the thigh meat was performed immediately after slaughter (day 0 ) and after storage for 7,30 , and 60 days at $-20^{\circ} \mathrm{C}$. The analyses were performed according Vince (1970) and Sorensen and Jorgensen (1996). The aldehydes were extracted by mixing $10 \mathrm{~mL}$ of trichloroacetic acid solution (7.5\%) (Inlab, São Paulo, Brazil) and BHT (0.2\%) (Sigma Aldrich, São Paulo, Brazil) with $2.5 \mathrm{~g}$ sample. The resultant supernatant was filtered through qualitative filter paper, and then $3 \mathrm{~mL}$ of thiobarbituric acid solution (0.02 M) (Sigma Aldrich, São Paulo, Brazil) was added to $3 \mathrm{~mL}$ of the solution (1:1 v/v). This solution was kept in a water bath at $80{ }^{\circ} \mathrm{C}$ for $40 \mathrm{~min}$, and absorbance was measured using a spectrophotometer (Evolution ${ }^{\mathrm{TM}} 300$ e Thermo Scientific) at $538 \mathrm{~nm}$. A calibration curve was plotted with 1,1,3,3-tetraethoxypropane (Sigma Aldrich, São Paulo, Brazil), and the results were expressed as malonaldehyde (MDA)/mg meat.

The results were submitted to analysis of variance (ANOVA) and polynomial regression. Dunnett's test $(P>0.05)$ was used to compare the control $(0 \mathrm{mg} / \mathrm{kg} \mathrm{HEGP)}$ with the treatment groups $(100,200,300,400$, and $500 \mathrm{mg} / \mathrm{kg}$ HEGP) using SAS® university edition statistical software (2017) (SAS Inst., Inc., Cary, NC, USA). Data on TBARS were subjected to ANOVA using the PROC GLM procedure of SAS (2017) to test the individual effects of HEGP inclusion levels and storage time, and their interaction. Significant interactions $(P$ $<0.05$ ) were revealed by applying polynomial regression equations to evaluate the HEGP inclusion levels at $0,7,30$, and 60 days of storage.

\section{Results and Discussion}

The levels of total polyphenols and flavonoids in the HEGP were $47.80 \mathrm{mg} \mathrm{GAE} / \mathrm{L}$ and $10.99 \mathrm{mg}$ $\mathrm{QE} / \mathrm{L}$, respectively.

There was a quadratic effect of dietary HEGP inclusion $(P<0.05)$ on WG and FCR of broilers from 21 to 42 days old. According to the adjusted equations, HEGP levels of 314 and $219 \mathrm{mg} / \mathrm{kg}$ resulted in greater $W G$ and better FCR, respectively. The AFI increased $(P<0.05)$ with rising extract levels in diets. Moreover, broilers fed diets containing 200 to $500 \mathrm{mg} / \mathrm{kg}$ of HEGP had greater WG compared with animals fed with extract-free diet, and animals fed diets containing 100, 200,300, and $500 \mathrm{mg} / \mathrm{kg}$ of HEGP had greater AFI compared with control broilers (Table 2).

There was no effect of HEGP inclusion $(P>0.05)$ on carcass yield, the yield of special cuts (wings, legs, and breast) and abdominal fat percentage. No significant difference $(P>0.05)$ was observed for all yield traits when comparing each HEGP inclusion level with the control treatment (Table 3).

There was a quadratic effect of HEGP inclusion $(P<0.05)$ on WHC, with the greatest WHC calculated at $263 \mathrm{mg} / \mathrm{kg}$ extract. The $\mathrm{CL}$ increased $(P<0.05)$ with increasing extract levels in diets. No significant difference $(P>0.05)$ was observed for WHC and CL when comparing each HEGP inclusion level with the control treatment. The SF was not affected $(P>0.05)$ by the inclusion of HEGP in diets (Table 4).

There was a quadratic effect of HEGP inclusion $(P<0.05)$ on $a^{*}$ (redness/greenness) of thigh meat at $15 \mathrm{~min}$ post-mortem, with the lowest redness calculated at the level of $270 \mathrm{mg} / \mathrm{kg} \mathrm{HEGP}$. No significant difference $(P>0.05)$ was observed for $\mathrm{pH}$ and meat colour traits when each HEGP inclusion level was compared with the control (Table 5). 
Table 2 Performance of broiler chickens from 21 to 42 days old fed diets containing various levels of hydroethanolic extract of guavira peel

\begin{tabular}{|c|c|c|c|}
\hline HEGP Inclusion, mg/kg & WG $(g)$ & AFI $(g)$ & FCR \\
\hline 0 & 1935 & 3511 & 1.817 \\
\hline 100 & 2042 & $3702^{*}$ & 1.813 \\
\hline 200 & $2119^{*}$ & $3712^{*}$ & 1.751 \\
\hline 300 & $2124^{*}$ & $3789^{*}$ & 1.785 \\
\hline 400 & $2085^{\star}$ & 3675 & 1.762 \\
\hline 500 & $2075^{*}$ & $3772^{*}$ & 1.818 \\
\hline Standard error & 8.70 & 10.75 & 0.172 \\
\hline$P$-value & 0.012 & 0.018 & 0.132 \\
\hline$P$-value: regression on HEGP level & $0.003(Q)$ & $0.015(\mathrm{~L})$ & $0.029(Q)$ \\
\hline Equations & $\mathrm{R}^{2}$ & HEGP & Result \\
\hline$W G=1942.10764+1.175963 x-0.0000187 x^{2}$ & 0.95 & $314 \mathrm{mg} / \mathrm{kg}$ & 2126 \\
\hline$F I=3600,651067+0.37117 x$ & 0.49 & & \\
\hline$F C R=1.8267-0.000438 x+0.000001 x^{2}$ & 0.61 & $219 \mathrm{mg} / \mathrm{kg}$ & 1.769 \\
\hline
\end{tabular}

Table 3 Carcass, portion yield (\%), and abdominal fat (\%) of broiler chickens at 42 days old fed diets containing levels of hydroethanolic extract of guavira peel

\begin{tabular}{lccccc}
\hline HEGP Inclusion, $\mathrm{mg} / \mathrm{kg}$ & Carcass & Wings & Thigh and leg & Breast & Abdominal fat \\
\hline 0 & 69.80 & 10.38 & 32.66 & 41.41 & 2.40 \\
100 & 69.67 & 10.17 & 33.52 & 40.13 & 2.68 \\
200 & 71.20 & 10.17 & 33.03 & 41.19 & 2.51 \\
300 & 70.02 & 10.28 & 33.13 & 40.99 & 2.76 \\
400 & 70.77 & 10.04 & 32.43 & 41.19 & 2.41 \\
500 & 70.13 & 10.05 & 32.14 & 41.83 & 2.73 \\
\hline SEM & 0.771 & 0.362 & 0.711 & 0.752 & 0.404 \\
$P$-value & 0.697 & 0.528 & 0.343 & 0.565 & 0.718 \\
$P$-value regression on HEGP level & 0.550 & 0.800 & 0.734 & 0.595 & 0.506 \\
\hline
\end{tabular}

HEGP: hydroethanolic extract of guavira peel 
Table 4 Water-holding capacity, cooking loss and shear force values of breast meat of broiler chickens at 42 days old fed diets containing levels of hydroetahnolic extract of guavira peel

\begin{tabular}{lccc}
\hline HEGP inclusion, $\mathrm{mg} / \mathrm{kg}$ & WHC (\%) & CL (\%) & $\mathrm{SF}\left(\mathrm{kgf} / \mathrm{cm}^{2}\right)$ \\
\hline 0 & 75.46 & 27.09 & 3.03 \\
100 & 78.70 & 27.19 & 3.04 \\
200 & 82.51 & 26.95 & 3.24 \\
300 & 78.51 & 29.00 & 3.02 \\
400 & 78.17 & 29.74 & 2.79 \\
500 & 76.09 & 30.36 & 2.61 \\
\hline SEM & 1.577 & 1.225 & 0.467 \\
$P$-value & 0.256 & 0.230 & 0.904 \\
$P$ regression & $0.032(\mathrm{Q})$ & $0.021(\mathrm{~L})$ & 0.318 \\
Equation & $\mathrm{R}^{2}$ & $\mathrm{HEGP}$ & $\mathrm{R}$ \\
WHC $=76,8458+0,0368 \mathrm{x}-0,00007 \mathrm{x}^{2}$ & 0.73 & $262.86 \mathrm{mg} / \mathrm{kg}$ & 81.68 \\
CL $=26,576+0,0066 \mathrm{x}$ & 0.80 & &
\end{tabular}

HEGP: hydroethanolic extract of guavira peel, WHC: water-holding capacity, CL: cooking loss, SF: shear force 
Table 5 Colour and $\mathrm{pH}$ values of breast and thigh meat of broilers, at 42 days old, fed diets containing levels of hydroethanolic extract of guavira peel excised at $15 \mathrm{~min}$ and 24 hours post-mortem

\begin{tabular}{|c|c|c|c|c|c|c|c|c|c|c|c|c|}
\hline \multirow[b]{3}{*}{ HEGP inclusion, mg/kg } & \multicolumn{4}{|c|}{$\mathrm{pH}$} & \multicolumn{4}{|c|}{$\mathrm{L}^{*}$} & \multicolumn{4}{|c|}{$a^{*}$} \\
\hline & \multicolumn{2}{|c|}{$15 \mathrm{~min}$} & \multicolumn{2}{|c|}{$24 \mathrm{~h}$} & \multicolumn{2}{|c|}{$15 \mathrm{~min}$} & \multicolumn{2}{|c|}{$24 \mathrm{~h}$} & \multicolumn{2}{|c|}{$15 \min$} & \multicolumn{2}{|c|}{$24 \mathrm{~h}$} \\
\hline & Breast & Thigh & Breast & Thigh & Breast & Thigh & Breast & Thigh & Breast & Thigh & Breast & Thigh \\
\hline 0 & 6.07 & 5.88 & 5.64 & 5.83 & 45.91 & 49.35 & 52.44 & 51.30 & 3.438 & 4.99 & 3.43 & 5.21 \\
\hline 100 & 6.26 & 5.99 & 5.50 & 5.63 & 46.22 & 51.21 & 55.21 & 52.67 & 2.703 & 3.33 & 1.77 & 3.23 \\
\hline 200 & 6.08 & 5.91 & 5.70 & 5.65 & 44.74 & 50.07 & 52.29 & 51.92 & 3.553 & 3.72 & 2.62 & 4.77 \\
\hline 300 & 6.18 & 5.94 & 5.69 & 5.74 & 45.72 & 50.32 & 53.63 & 52.38 & 3.053 & 3.58 & 2.27 & 3.29 \\
\hline 400 & 6.14 & 5.98 & 5.57 & 5.74 & 48.84 & 48.87 & 52.32 & 50.82 & 3.614 & 3.56 & 4.26 & 3.28 \\
\hline 500 & 6.16 & 5.96 & 5.50 & 5.78 & 47.97 & 48.77 & 53.90 & 50.84 & 3.712 & 4.55 & 3.12 & 4.67 \\
\hline SEM & 0.265 & 0.177 & 0.299 & 0.272 & 1.239 & 0.971 & 1.082 & 0.888 & 0.624 & 0.811 & 0.94 & 0.095 \\
\hline$P$-value & 0.553 & 0.671 & 0.071 & 0.123 & 0.215 & 0.274 & 0.473 & 0.627 & 0.392 & 0.116 & 0.023 & 0.107 \\
\hline$P$-value regression on HEGP level & 0.313 & 0.505 & 0.930 & 0.226 & 0.410 & 0.488 & 0.224 & 0.728 & 0.284 & $0.012(\mathrm{~L})$ & 0.281 & 0.129 \\
\hline Equation & & & & & & $\mathrm{R}^{2}$ & & & & HEGP & & \\
\hline \multicolumn{5}{|c|}{$\mathrm{a}^{*}$ Thigh $15 \mathrm{~min}=4.7668-0.0108 \mathrm{x}+0.00002 \mathrm{x}^{2}$} & & 0.76 & & & & $270 \mathrm{mg} / \mathrm{kg}$ & & \\
\hline
\end{tabular}

$\mathrm{L}^{*}$ : Lightness, $\mathrm{a}^{*}$ : redness, $\mathrm{b}^{*}$ : yellowness, L: linear 
An interaction $(P<0.05)$ between inclusion levels of extract and storage period was observed for TBARS. Overall, the sliced data show that within each storage time there was only a quadratic influence $(P$ $<0.05$ ) of the dietary inclusion levels of the extract on the malonaldehyde (MDA) contents at 30 -day storage, with the highest MDA value being calculated at $218 \mathrm{mg} / \mathrm{kg}$ HEGP (Table 6).

Table 6 Values of thiobarbituric acid reactive substances ( $\mathrm{mg}$ malonaldehyde/ $\mathrm{kg}$ meat) of thigh meat of broiler chickens at 42 days old fed diets containing levels of hydroetahnolic extract of guavira peel and evaluated at various storage times $(0,7,30$ and 60 days)

\begin{tabular}{|c|c|c|c|c|c|c|}
\hline \multirow{2}{*}{ HEGP inclusion, mg/kg } & \multicolumn{5}{|c|}{ Storage times } & \multirow[b]{2}{*}{ SE } \\
\hline & 0 & 7 & 30 & 60 & Average & \\
\hline 0 & 0.264 & 0.468 & 0.225 & 0.110 & 0.267 & 0.0037 \\
\hline 100 & 0.254 & 0.430 & 0.236 & 0.109 & 0.257 & 0.0038 \\
\hline 200 & 0.262 & 0.433 & 0.237 & 0.109 & 0.260 & 0.0039 \\
\hline 300 & 0.266 & 0.447 & 0.241 & 0.109 & 0.266 & 0.0037 \\
\hline 400 & 0.269 & 0.444 & 0.234 & 0.108 & 0.264 & 0.0037 \\
\hline 500 & 0.287 & 0.444 & 0.207 & 0.108 & 0.262 & 0.0038 \\
\hline Average & 0.267 & 0.444 & 0.230 & 0.109 & & \\
\hline SEM & 0.0034 & 0.0029 & 0.0029 & 0.0029 & & \\
\hline$P$-values & \multicolumn{6}{|c|}{ HEGP level $=0.432$, Time $<0.001$, Interaction $=0.006$} \\
\hline \multicolumn{4}{|c|}{ Regression of TBARS at 30 days (y) on HEGP level $(x)$} & $\mathrm{R}^{2}$ & HEGP & Result \\
\hline \multicolumn{4}{|c|}{$y=0.223+0.00172 x-0.000001 x^{2}$} & .91 & $218 \mathrm{mg} / \mathrm{kg}$ & 0.230 \\
\hline
\end{tabular}

TBARS: thiobarbituric acid reactive substances, HEGP: hydroetahnolic extract of guavira peel

Bioactive compounds such as polyphenols and flavonoids are known for their antioxidant, antiinflammatory, and antimicrobial effects (Viecili et al., 2014; Capeletto et al., 2016). Thus, the levels of total polyphenols and flavonoids in HEGP show the potential of this extract as a natural additive (Auharek et al., 2013).

Bioactive compounds may stimulate the digestive process, thus providing higher feed digestibility and nutrient absorption (Ader et al., 2000; Perić et al., 2009). Recent studies identified correlations between natural substances and modulation of growth performance, intestinal microbiota and intestinal quality (Fascina et al., 2017; Zhu et al., 2019). The anti-inflammatory and immunomodulatory properties of these compounds must also be considered. Natural extracts could reduce the gene expression of cytokines involved in the inflammatory response at intestinal level (Herrero-Encinas et al., 2020), leading to improved animal performance.

In terms of performance data, a dose-dependent effect was observed in this study, which was associated with the compounds remaining in the intestinal lumen, with local action, since the absorption rate of phenolic compounds is considered low in chickens (Brenes et al., 2008). Phenolic compounds may reduce glucose absorption by interfering with the expression of the GLUT2 glucose transport protein (Kwon et al., 2007), which would impair animal performance. In this context, Eyng et al. (2014) observed a linear reduction in saccharase activity in the duodenal mucosa of seven-day-old broilers fed diets containing up to $5000 \mathrm{mg} / \mathrm{kg}$ of ethanolic propolis extract. The authors reported a reduction in productive parameters, correlating the capability of phenolic compounds with alteration of carbohydrate metabolism and interference with monosaccharide absorption. Thus, attention should be paid to the dietary inclusion level of natural extracts in broiler diets.

In addition, the presence of these substances was correlated with improved meat quality owing to their antioxidant action (Starčević et al., 2015), which influences sensory characteristics.

In this study a reduction on thigh muscle redness $\left(a^{*}\right)$ at 15 min post-mortem was observed in response to inclusion of HEGP. Myoglobin is responsible for meat colour and contains an iron molecule in the ferrous state (Fe II). When exposed to oxygen, Fe II is transformed into Fe III, a state named metmyoglobin, which is accompanied by changes in meat colour and quality (Papuc et al., 2017). Inai et al. (2014) demonstrated the in vitro ability of polyphenols to control the redox state of myoglobin. However, the presumably low bioavailability of these substances in humans and animals may have impaired their 
antioxidant action. Thus, the protective action of polyphenols may be reduced when added to feeds because it is dependent on the processes of digestion, absorption, metabolism, and tissue deposition (Surai et al., 2014). Despite the influence at 15 min post-mortem, the colour of meat samples at 24 hours post-mortem was considered normal (Barbut, 1997) as the dietary inclusion of HEGP did not affect the quality of the final product.

Meat tenderness is associated directly with $\mathrm{WHC}$ and $\mathrm{CL}$, and consumers regard these attributes as fundamental traits. An increased muscle $\mathrm{pH}$ was correlated with enhanced WHC and meat tenderness, resulting in better quality meat (Selim et al., 2013). Although no influence of extract levels on pH and SF was observed, there was an improvement in WHC. The active compounds in extracts can reduce protein oxidation and modulate the action of the enzymatic complex formed by calpain (Guttmann \& Johnson, 1998; Huff-Lonergan \& Lonergan, 2005) through their antioxidant action. These factors are related directly to WHC, affecting the quality of the final product.

Oxidation of meat lipid and protein components, which generates free radicals, is responsible for the quality deficiency owing to the loss of colour pigmentation, reduction in shelf life, the formation of toxic compounds, and deficit of nutrients (Contini et al., 2014; Falowo et al., 2014). Polyphenols are potent antioxidant agents that are capable of scavenging free radicals, largely by acting as metal ion-chelating molecules that catalyse oxidation reactions, delaying this process. In this context, phenolic groups donate hydrogen ions and prevent free radical generation, with the formation of stable end products (Zhang et al., 2016).

Despite evidence for the antioxidant property of phenolic compounds and their ability to be incorporated in meat products (Saleh et al., 2017), no reduction in meat lipid oxidation was observed when HEGP was included in the diets, rejecting the hypothesis that the inclusion of guavira extract in broiler diets could improve meat quality. The absorption of flavonoids depends on their physico-chemical properties, and the metabolization of these components involves processes of hydrolyzation, glucuronidation, sulfation, and methylation, which seems similar to mammal uptake (Rupasinghe et al., 2010; Fotakis et al., 2017). The mechanism of action of extracts may be related to the absorption and deposition of the phenolic compounds because, when absorbed, they are quickly metabolized, and a large part is eliminated by the kidneys (Lee et al. 2004). Kamboh et al. (2019) emphasized that the unabsorbed flavonoids from the small intestine, and some of the absorbed compounds, are secreted with bile, being after being degraded in the large intestine by the microbiota. Rupasinghe et al. (2010) observed that quercetin glucosides, which belong to a subgroup of flavonoids, can be absorbed and metabolized by broiler chickens. However, the absorption of the component was not sufficient to elevate the antioxidant capacity of the tissues (Rupasinghe et al., 2010). In this sense, the direct use of these compounds in raw meat reduced lipid oxidation, increasing the shelf life of meat products (Krishnan et al., 2014; Nikmaram et al., 2018). Nunes et al. (2019) observed a reduction in lipid oxidation in eggs of laying quails fed diets containing dehydrated bocaiúva (Acrocomia aculeata) pulp, emphasizing that the antioxidants added to feed were preferentially incorporated in eggs rather than meat because the biological priority is to ensure the development of the embryo.

\section{Conclusions}

The dietary inclusion of $219 \mathrm{mg} / \mathrm{kg}$ of hydroethanolic extract of guavira fruit peel resulted in better FCR for broilers in the finishing phase but without changing the carcass characteristics. However, in terms of meat quality, it was not possible to verify the antioxidant capacity of this extract.

\section{Acknowledgements}

Funding was provided by the Coordenação de Aperfeiçoamento de Pessoal de Nível Superior (CAPES) (Brazil) (Finance code 001) and Conselho Nacional de Desenvolvimento Científico e Tecnológico (CNPq) (Brazil).

\section{Authors' Contributions}

CE and RVN designed the study and were the supervisors. EJSA and CACC were in charge of extract production. MLL worked on the project, and laboratory analysis. TLK and APGCC participated in management and discussion of the results, statistical analysis and writing, and corrected the manuscript.

\section{Conflict of Interest Declaration}

The authors declare that they have no conflicts of interest relative to the content of this paper.

\section{References}

Ader, P., Wessmann, A. \& Wolffram, S., 2000. Bioavailability and metabolism of the flavonol quercetin in the pig. Free Radic. Biol. Med. 28, 1056-1067. https:// doi.org/10.1016/s0891-5849(00)00195-7

Auharek, S.A., Vieira, M.C., Cardoso, C.A.L., Oliveira, R.J. \& Cunha-Laura, A.L., 2013. Reproductive toxicity of Campomanesia xanthocarpa (Berg.) in female Wistar rats. J. Ethnopharmacol. 148, $341-343$. https://doi.org/10.1016/j.jep.2013.04.010 
Barbut, S., 1997. Problem of pale soft exudative meat in broiler chickens. Br. Poult. Sci. 38, 355-358. https://doi.org/10.1080/00071669708418002

Brenes, A., Viveros, A., Goni, I., Centeno, C., Sayago-Ayerdi, S.G., Arija, I. \& Saura-Calixto, F., 2008. Effect of grape pomace concentrate and vitamin $E$ on digestibility of polyphenols and antioxidant activity in chickens. Poult. Sci. 87, 307-316. https://doi.org/10.3382/ps.2007-00297

Buriol, L., Finger, D., Schmidt, E.M., Santos, J.M.T., Rosa, M.R., Quináia, S.P., Torres, Y.R., Santa, H.S.D., Pessoa, C., Moraes, M.O., Costa-Lotufo, L.V., Ferreira, P.M.P., Sawaya, A.C.H.F. \& Eberlin, M.N., 2009. Chemical composition and biological activity of oil própolis extract: An alternative to ethanolic extract. Quím. Nova. 32, 296302. https://doi.org/10.1590/S0100-40422009000200006 (in Portuguese, English abstract)

Capeletto, C., Conterato, G., Scapinello, J., Rodrigues, F.S., Copini, M.S., Kuhn, F., Tres, M.V., Magro, J.D. \& Oliveira, J.V., 2016. Chemical composition, antioxidant and antimicrobial activity of guavirova (Campomanesia xanthocarpa Berg) seed extracts obtained by supercritical $\mathrm{CO}_{2}$ and compressed $n$-butane. J. Supercrit. Fluids. 110, 32-38. https://doi.org/10.1016/j.supflu.2015.12.009

Contini, C., Alvarez, R., O'Sullivana, M., Dowling, D.P., Gargan, S.O. \& Monahan, F.J., 2014. Effect of an active packaging with citrus extract on lipid oxidation and sensory quality of cooked turkey meat. Meat Sci. 96, 11711176. https://doi.org/ 10.1016/j.meatsci.2013.11.007

Eyng, C., Murakami, A.E., Duarte, C.R.A. \& Santos, T.C., 2014. Effect of dietary supplementation with an ethanolic extract of propolis on broiler intestinal morphology and digestive enzyme activity. J. Anim. Physiol. Anim. Nutr. 98, 393-401. https://pubmed.ncbi.nlm.nih.gov/23909488/

Falowo, A.B., Fayemi, P.O. \& Muchenje, V., 2014. Natural antioxidants against lipid-protein oxidative deterioration in meat and meat products: A review. Food Res. Int. 64, 171-181. https://doi.org/10.1016/j.foodres.2014.06.022

Fascina, V.B., Pasquali, G.A.M., Carvalho, F.B., Muro, E.M., Vercese, F.I., Aoyagi, M.M., Pezzato, A.C., Gonzales, E. \& Sartori, J.R., 2017. Effects of phytogenic additives and organic acids, alone or in combination, on the performance, intestinal quality and immune responses of broiler chickens. Braz. J. Poult. Sci. 19(3), 497-508. https://doi.org/10.1590/1806-9061-2016-0422

Fotakis, C., Lantzouraki, D.Z., Goliomytis, M., Simitzis, P.E., Charismiadou, M., Deligeorgis, G. \& Zoumpoulakis, P. 2017. NMR metabolomics investigates the influence of flavonoid-enriched rations on chicken plasma. J. AOAC Int. 100(2), 315-322. https://doi.org/10.5740/jaoacint.16-0405

Fronning, G.W. \& Uijttenboogaart, T.G., 1988. Effect of postmortem electrical stimulation on color, texture, $\mathrm{pH}$ and cooking losses of hot and cold deboned chicken broiler breast meat. Poult. Sci. 67, 1536-1544. https://doi.org/10.3382/ps.0671536

Garcia-Migura, L., Hendriksen, R.S., Fraile, L. \& Aarestrup, F.M., 2014. Antimicrobial resistance of zoonotic and commensal bacteria in Europe: The missing link between consumption and resistance in veterinary medicine. Vet. Microbiol. 170, 1-9. https://doi.org/10.1016/j.vetmic.2014.01.013

Guttmann, R.P. \& Johnson, G.V., 1998. Oxidative stress inhibits calpain activity in situ. J. Biol. Chem. 273(21), 1333113338. https://doi.org/10.1074/jbc.273.21.13331

Herrero-Encinas, J., Blanch, M., Pastor, J.J., Mereu, A., Ipharraguerre, I.R. \& Menoyo, D., 2020. Effects of a bioactive olive pomace extract from Olea europaea on growth performance, gut function, and intestinal microbiota in broiler chickens. Poult. Sci. 99(1), 1-9. https://doi.org/10.3382/ps/pez467

Honikel, K.O., 1998. Reference methods for the assessment of physical characteristics of meat. Meat Sci. 49, $447-457$. https://doi.org/10.1016/S0309-1740(98)00034-5

Huff-Lonergan, E. \& Lonergan, S.M., 2005. Mechanisms of water-holding capacity of meat: The role of postmortem biochemical and structural changes. Meat Sci. 71, 194-204. https://doi.org/10.1016/j.meatsci.2005.04.022

Huyghebaert, G., Dacatelle, R. \& Van Immerseel, F., 2011. An update on alternatives to antimicrobial growth promoters for broilers. Vet. J. 187(2), 182-188. https://doi.org/ 10.1016/j.tvjl.2010.03.003

Inai, M., Miura, Y., Honda, S., Masuda, A. \& Masuda, T., 2014. Metmyoglobin reduction by polyphenols and mechanism of the conversion of metmyoglobin to oxymyoglobin by quercetin. J. Agric. Food Chem. 62(4), 893-901. https://doi.org/10.1021/jf404357h

Jamroz, D., Wertelecki, T., Houszka, M. \& Kamel, C., 2006. Influence of diet type on the inclusion of plant origin active substances on morphological and histochemical characteristics of the stomach and jejunum walls in chicken. J. Anim. Physiol. Anim. Nutr. 90(5-6), 255-268. https://onlinelibrary.wiley.com/doi/abs/10.1111/j.1439-0396.2005.00603.x

Jiang, J. \& Xiong, Y.L., 2016. Natural antioxidants as food and feed additives to promote health benefits and quality of meat products: a review. Meat Sci. 120, 107-117. https://doi.org/10.1016/j.meatsci.2016.04.005

Kamboh, A.A., Arain, M.A., Mughal, M.J., Zaman, A., Arain, Z.M. \& Soomro, A.H., 2015. Flavonoids: Health promoting phytochemicals for animal production - A review. J. Anim. Health Prod. 3(1), 6-13. http://doi.org/10.14737/journal.jahp/2015/3.1.6.13

Kamboh, A.A., Leghari, R.A., Khan, M.A., Kaka, U., Naseer, M., Sazili, A.Q. \& Malhi, K.K. 2019. Flavonoids supplementation - An ideal approach to improve quality of poultry products. Worlds Poult. Sci. J. 75(1), 115-126. https://doi.org/10.1017/S0043933918000703

Krishnan, K.R., Babuskin, S., Babu, P.A.S., Sasikala, M., Sivarajan, M. \& Sukuma, M., 2014. Antimicrobial and antioxidant effects of spice extracts on the shelf life extension of raw chicken meat. Int. J. Food Microbiol. 171, 32 40. https://doi.org/10.1016/j.ijfoodmicro.2013.11.011

Kwon, O., Eck, P., Chen, S., Corpe, C.P., Lee, J.H., Kruhlak, M. \& Levine, M., 2007. Inhibition of the intestinal glucose transporter GLUT2 by flavonoids. FASEB J. 21(2), 366-377. https://doi.org/10.1096/fj.06-6620com 
Lee, K.W., Everts, H. \& Beynen, A.C., 2004. Essential oils in broiler nutrition. International Journal of Poult. Sci. 3(12), 738-752. https://doi.org/10.3923/ijps.2004.738.752

Nakamura, M. \& Katok, K., 1985. Influence of thawing method on several properties of rabbit meat. Bull. Ishika Prefect. Coll. Agric. 11, 45-49.

Nikmaram, N., Budaraju, S., Barba, F.J., Lorenzo, J.M., Cox, R.B., Mallikarjunan, K. \& Roohineja, S., 2018. Application of plant extracts to improve the shelf-life, nutritional and health-related properties of ready-to-eat meat products. Meat Sci. 145, 245-255. https://doi.org/10.1016/j.meatsci.2018.06.031

Nunes, K.C., Eyng, C., Pintro, P.T.M., Garcia, R.G., Murakami, A.E., Vital, A.C.P., Nunes, R.V. \& Nesello, P.O., 2019. Dietary inclusion of dehydrated bocaiuva pulp increases the antioxidant potential of quail eggs. J. Anim. Physiol. Anim. Nutr. 103(1), 64-71. https://doi.org/10.1111/jpn.13003

Oleforuh-Okoleh, V.U., Ndofor-Foleng, H.M., Olorunleke, S.O. \& Uguru, J.O., 2015. Evaluation of growth performance, hematological and serum biochemical response of broiler chickens to aqueous extract of ginger and garlic. J. Agric. Sci. 7, 167-173. https://doi.org/10.5539/jas.v7n4p167

Papuc, C., Goran, G.V., Predescu, C.N., Nicorescu, V. \& Stefan, G., 2017. Plant polyphenols as antioxidant and antibacterial agents for shelf-life extension of meat and meat products: Classification, structures, sources, and action mechanisms. Compr. Rev. Food Sci. F. 16(6), 1243-1268. https://doi.org/10.1111/1541-4337.12298

Pascoal, A.C.R.F., Ehrenfried, C.A., Eberlin, M.N., Stefanello, M.E.A. \& Salvador, M.J., 2011. Free radical scavenging activity, determination of phenolic compounds and HPLC-DAD/ESI-MS profile of Campomanesia adamantium leaves. Nat. Prod. Commun. 6(7), 969-972.

Pereira, M.C., Steffens, R.S., Jablonski, A., Hertz, P.F., Rios Ade, O., Vizzotto, M. \& Flôres, S.H., 2012. Characterization and antioxidant potential of Brazilian fruits from the Myrtaceae family. J. Agric. Food Chem. 60(12), 3061-3067. https://doi.org/ 10.1021/jf205263f

Perić, L., Žikić, D. \& Lukić, M., 2009. Application of alternative growth promoters in broiler production. Biotech. Anim. Husbandry, 25, 387-397. https://www.researchgate.net/publication/247874085_Application_ of_alternative_growth_promoters_in_broiler_production

Rostagno, H.S., Albino, L.F.T., Hannas, M.I., Donzele, J.L., Sakomura, N.K., Perazzo, F.G., Saraiva, A., Teixeira, M.V., Rodrigues, P.B., Oliveira, R.F., Barreto, S.L.T. \& Brito, C.O., 2017. Brazilian tables for poultry and swine: food composition and nutritional requirements. 4 nd ed. Universidade Federal de Viçosa, Viçosa, MG. 488p.

Rupasinghe, H.P.V., Ronalds, C.M., Rathgeber, B. \& Robinson, R.A. 2010. Absorption and tissue distribution of dietary quercetin and quercetin glycosides of apple skin in broiler chickens. J. Sci. Food Agric. 90, 1172-1178. https://doi.org/10.1002/jsfa.3944

Sakomura, N.K. \& Rostagno, H.S., 2016. Monogastric nutrition research methods. 2nd ed. Jaboticabal: Funep. 262 p.

Saleh, H., Golian, A., Kermanshahi, H. \& Mirakzehi, M.T., 2017. Effects of dietary a-tocopherol acetate, pomegranate peel, and pomegranate peel extract on phenolic content, fatty acid composition, and meat quality of broiler chickens. J. Appl. Anim. Res. 45(1), 629-636. https://doi.org/10.1080/09712119.2016.1248841

Selim, N.A., Nada, S.A., Abdel-Salam, A.F. \& Youssef, S.F., 2013. Evaluation of some natural antioxidant sources in broiler diets: 2-effect on chemical and microbiological quality of chilled and frozen broiler meat. Int. J. Poult. Sci. 12(10), 572-581. https://doi.org/10.3923/ijps.2013.572.581

Singleton, V.L. \& Rossi, J.A., 1965. Colorimetry of total phenolics with phosphomolybdic-phosphotungstic acid reagents. Am. J. Enol. Viticult. 16, 144-158.

Sorensen, G. \& Jorgensen, S.S., 1996. A critical examination of some experimental variables in the 2-thiobarbituric acid (TBA) test for lipid oxidation in meat products. Z. Lebensm. Unters. Forsch. 202, 205-210.

Starčević, K., Krstulović, L., Brozić, D., Maurić, M., Stojević, Z., Mikulec, Ž., Bajić, M. \& Mašek, T., 2015. Production performance, meat composition and oxidative susceptibility in broiler chicken fed with different phenolic compounds. J. Sci. Food Agric. 95(6), 1172-1178. https://doi.org/10.1002/jsfa.6805

Surai, P.F., 2014. Polyphenol compounds in the chicken/animal diet: from the past to the future. J. Anim. Physiol. Anim. Nutr. 98(1), 19-31. https://doi.org/10.1111/jpn.12070

Vallilo, M.I., Lamardo, L.C.A., Gaberlotti, M.L., Oliveira, E. \& Moreno, P.R.H., 2006. Chemical composition of Campomanesia adamantium (Cambessédes) O. berg' fruits. Ciênc. Tecnol. Aliment. 26(4), 805-810. https://doi.org/10.1590/S0101-20612006000400015 (in Portuguese, English abstract).

Viecili, P.R.N., Borges, D.O., Kirsten, K., Malheiros, J., Viecili, E., Melo, R.D., Trevisan, G., Silva, M.A., Bochi, G.V., Moresco, R.N. \& Klafke, J.Z., 2014. Effects of Campomanesia xanthocarpa on inflammatory processes, oxidative stress, endothelial dysfunction and lipid biomarkers in hypercholesterolemic individuals. Atherosclerosis. 234(1), 85-92. https://doi.org/10.1016/j.atherosclerosis.2014.02.010

Vyncke, W., 1970. Direct determination of the thiobarbituric acid value in trichloracetic acid extracts of fish as a measure of oxidative rancidity. Eur. J. Lipid Sci. Technol. 72, 1084-1087. https://doi.org/10.1002/lipi.19700721218

Windisch, W., Schedle, K., Plitzner, C. \& Kroismayr, A. 2008. Use of phytogenic products as feed additives for swine and poultry. J. Anim. Sci. 86(14 Suppl.), 140-148. https://doi.org/ 10.2527/jas.2007-0459

Zhang, H., Wu, J. \& Guo, X., 2016. Effects of antimicrobial and antioxidant activities of spice extracts on raw chicken meat quality. Food Sci. Hum. Wellness. 5, 39-48. https://doi.org/10.1016/j.fshw.2015.11.003

Zhu, N., Wang, J., Yu, L., Zhang, Q., Chen, K. \& Baosheng, L., 2019. Modulation of growth performance and intestinal microbiota in chickens fed plant extracts or virginiamycin. Front. Microbiol. 10, 1-16. https://doi.org/10.3389/fmicb.2019.01333 